\title{
A Study on Cotton Fiber Stabilize Soil and its Effect on CBR Value
}

\author{
Brajesh Mishra \\ Assistant Engineer, U.P. Cane Development Department, Lucknow, India
}

\begin{abstract}
For improvement of soil properties natural fibers can be used with great advantage because they are locally/ readily available, biodegradable, economical and eco-friendly as well. Soil reinforced with natural fiber is responsible for noteworthy improvement in its shear strength, tensile strength and other engineering properties. The use of randomly distributed synthetic and natural fibers over last two decades have gained remarkable popularity and success. In this study samples of locally available soil reinforced with cotton fibers were considered for experimental investigations. California bearing ratio (CBR) test was performed on samples with and without reinforcement for obtaining CBR values of soil by preparing samples at its maximum dry density (MDD) corresponding to its optimum moisture content $(\mathrm{OMC})$. The cotton fiber content by dry weight of soil was taken as $0.3 \%, 0.6 \%$, $0.9 \%$, $1.2 \%$ and 1.5\%. Unsoaked and soaked CBR value corresponding to each cotton fiber content was determined in the laboratory as per specified procedure. From the test results it was observed that unsoaked and soaked CBR value of soil increases with fiber content up to $1.2 \%$ and then a slight decrease was marked. It was also noticed that the increase in CBR value of reinforced soil was appreciable at cotton fiber content of $1.2 \%$. This increase is responsible for reduction in the pavement crust thickness and ultimately economy in the cost of construction.
\end{abstract}

Keywords: CBR value, Cotton fiber, Maximum dry density (MDD), Optimum moisture content (OMC).

\section{Introduction}

From the very beginning the soil has been used as a construction material and as a support for foundation of various structures. Due to its poor mechanical properties it was always a challenge to engineers to improve its properties as per requirement of site conditions, type of structure and nature of loadings. Various studies have revealed that due to inclusion of reinforcement in the form of fibers in the soil has improved the engineering properties of soil. Fiber reinforced soil has a better resistance towards deformation under applied loadings. The properties which were improved are remarkable i.e. greater extensibility, small loss of post peak strength, isotropy in strength and absence of plane of weakness. Fiber reinforced is effective for all types of soils i.e. sand, silt and clays. Many countries have adopted the fiber reinforcement technique to stabilize soil for improvement of its engineering behavior. Many countries including India have used the natural materials like jute, coir and bamboo as reinforcement in soil. These materials are in abundance in country like India and other adjoining countries. These materials are locally available and hence they are cheaper. These materials are biodegradable in nature so they do not create any disposal problem and are ecofriendly. The use of these materials in rural construction activities is a boon for India as the cost of construction can be reduced. The effective utilization of these materials will result in uplift of rural economy as well. In 2011 Sen and Reddy have shown that natural fiber of jute possess highest tensile strength, can withstand decaying and effect of heat. Researchers Sivkumaar Babu and Vasudevan have shown that by coating fiber with Phenol and Bitumen, the durability of natural fiber can be increased. To calculate the effect of parameters like fiber orientation, fiber content, fiber area ratios and fiber stiffness Gray and Ohashi in 1983 have conducted several direct shear tests on dry sand reinforced with randomly distributed synthetic, natural and metallic fibers and gave following conclusions-
- An increase in shear strength is directly proportional to fiber area ratios.

- Shear strength envelopes for fiber- reinforced sand shows the existence of a threshold confining stress below which the fiber tries to slip or pull out.

Many researchers in past have used various types of randomly distributed fibers for reinforcing the soil to improve its performance. The prominent researchers who have utilized different fibers are listed below in the Table. 1 .

Table 1: Researchers and utilized fibers

\begin{tabular}{|c|c|}
\hline Name of Researchers & Fiber Utilized \\
\hline Andrews et.al,1986 & $\begin{array}{c}\text { Polymeric mesh } \\
\text { elements }\end{array}$ \\
\hline $\begin{array}{c}\text { Gray and Al Refeai,1986, Mahar and } \\
\text { Gray,1990, Consoli et. al,2002, Rao et } \\
\text { al, 2006, Chandra et al, 2008, Singh } \\
2011\end{array}$ & Synthetic fiber \\
\hline Fatani et al, 1999 & Metallic fiber \\
\hline Lawton et al, 1993 & $\begin{array}{c}\text { Multi-oriented } \\
\text { Polypropylene } \\
\text { elements }\end{array}$ \\
\hline Lekha,2004 and Vishnudas et al, 2006 & Coir geotextile \\
\hline Sivkumaar Babu and Vasudevan, 2008 & Coir fiber \\
\hline Singh and Yachang,2012 & Jute geotextile sheet \\
\hline
\end{tabular}

Based on the experimental results they concluded that stressstrain behavior of soil is improved by introduction of coirfiber into the soil and Jute Geotextile sheet was responsible for improvement in CBR value of fly ash appreciably. They also concluded that there was an increase in deviator stress at failure up to 3.5 times over the unreinforced soil. It was also observed by them that stiffness modulus of reinforced soil increases considerably which is responsible for significant reduction in immediate settlement of soil. Application of Jute fiber to improve subgrade characteristics was studied by Aggrawal and Sharma in 2010. They concluded that there was an increase in CBR value of subgrade up to $250 \%$ with introduction of bitumen coated jute fiber. Singh and Bagra in 


\section{International Journal of Science and Research (IJSR) \\ ISSN (Online): 2319-7064}

Index Copernicus Value (2013): 6.14 | Impact Factor (2014): 5.611

2013 have shown that there was significant increase in CBR value of soil up to $200 \%$ with jute fiber having varying length and diameters of fiber.

\section{Objectives}

- To study the effect of inclusion of cotton fiber as a reinforcement in the soil and its effect on CBR value of soil.

- To carry out CBR test to evaluate the CBR value of unsoaked and soaked samples of soils with and without the cotton fiber reinforcement.

- To compare CBR values of cotton fiber reinforced soil with unreinforced soil and .

- To obtain optimum cotton fiber content to produce best results.

\section{Materials and Methods}

3.1. Materials: The materials used for the purpose of investigations and study are listed below-

3.1.1. Soil: The locally available soil collected from nearby locality of Lucknow district, Uttar Pradesh a state of India was used for preparation of sample with and without reinforcement.

3.1.2. Cotton Fiber: The reinforcing element in this study was synthetic cotton fiber which was collected from local shop. The physical properties of cotton fiber is as under-

Table.2 Properties of cotton fiber

\begin{tabular}{|c|c|}
\hline Particulars & Value \\
\hline Length $(\mathrm{mm})$ & $15-55$ \\
\hline Diameter $(\mathrm{mm})$ & $0.01-0.03$ \\
\hline Color & Depends upon climatic conditions \\
\hline Polymer system & Linear, cellulose polymer \\
\hline
\end{tabular}

A typical picture of cotton fiber is shown below in Fig.2.

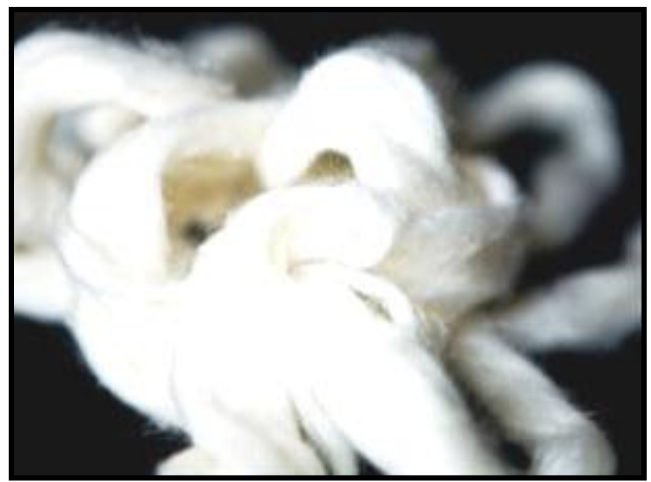

Figure 2: Cotton Fiber

\subsection{Method}

The required samples were prepared in accordance with the provision of concerned code of practice and as per prescribed procedure. The various properties like Index properties, compaction parameters and CBR value were determined. The category wise details are described as under-

\subsubsection{Index properties and compaction parameters}

The index properties and compaction parameters (maximum dry density and optimum moisture content) of locally available soil sample were determined in the laboratory as per specified procedures and guidelines. The values of various parameters are laid shown in Table. 3 below.

Table 3: Index properties and Compaction parameters

\begin{tabular}{|c|c|}
\hline Properties & Value \\
\hline Specific gravity(G) & 2.68 \\
\hline Liquid Limit (LL\%) & 23 \\
\hline Plastic Limit $(\mathrm{PL})$ & $\mathrm{NP}$ \\
\hline Gravel size $(>4.75 \mathrm{~mm}) \%$ & 0 \\
\hline Sand size $(0.075-4.75 \mathrm{~mm}) \%$ & 42 \\
\hline Silt size $(0.002-0.075 \mathrm{~mm}) \%$ & 55 \\
\hline Clay size $(<0.002 \mathrm{~mm}) \%$ & 3 \\
\hline Coefficient of Uniformity $(\mathrm{Cu})$ & 6.68 \\
\hline Coefficient of Curvature $(\mathrm{Cc})$ & 1.33 \\
\hline Maximum Dry Density $(\mathrm{MDD}) \mathrm{g} / \mathrm{cm}^{3}$ & 1.70 \\
\hline Optimum Moisture Content $(\mathrm{OMC}) \%$ & 15.86 \\
\hline
\end{tabular}

The particle size distribution curve (PSD) was plotted as shown in Fig. 2 below.

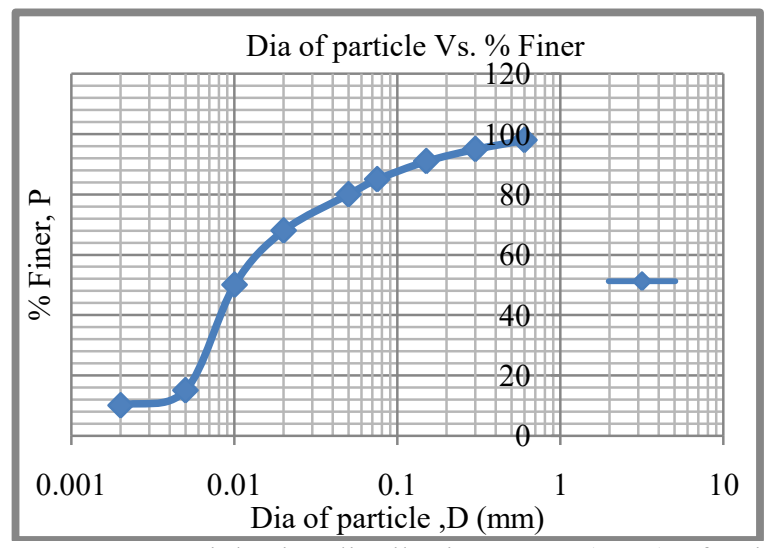

Figure 2: Particle size distribution curve (PSD) of Soil

\subsubsection{California Bearing Ratio (CBR) Test}

The soil samples for unreinforced and reinforced soil were prepared as per prescribed standard procedure and guidelines of IS codes and the CBR test was performed on both unsoaked

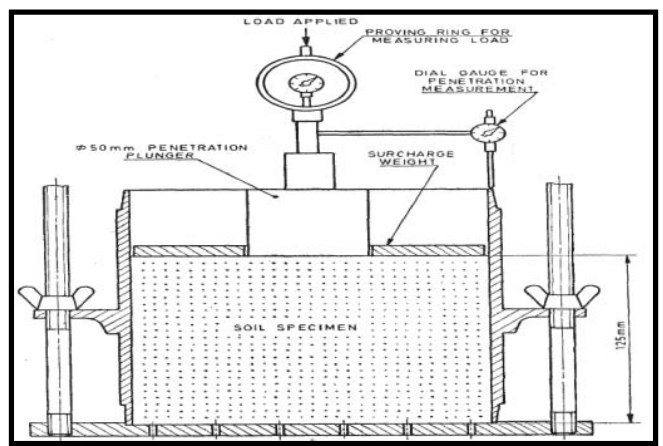

Figure 3: Set up for CBR Test

and soaked samples in accordance with the provision of IS:2720 Part 16-1987. The CBR values were determined accordingly. The set up for CBR test is shown in Fig. 3. 


\section{International Journal of Science and Research (IJSR) \\ ISSN (Online): 2319-7064}

Index Copernicus Value (2013): 6.14 | Impact Factor (2014): 5.611

\section{Results and Discussions}

The unsoaked and soaked CBR values were determined for both plain soil and reinforced soil with varying percentages of cotton fiber i.e. $0.3 \%, 0.6 \%, 0.9 \%, 1.2 \%$ and $1.5 \%$ by dry weight of soil. The results are tabled in Table. 4 as shown below-

Table 4: CBR value of Cotton fiber reinforced soil

\begin{tabular}{|c|c|c|}
\hline $\begin{array}{c}\text { Cotton fiber } \\
\text { content(\%) }\end{array}$ & $\begin{array}{c}\text { CBR Value } \\
(\%)\end{array}$ & $\begin{array}{c}\text { \% increase in } \\
\text { CBR Value }\end{array}$ \\
\hline \multicolumn{3}{|c|}{ Unsoaked CBR value } \\
\hline 0 & 10 & - \\
\hline 0.3 & 17.15 & 71.5 \\
\hline 0.6 & 18.30 & 83 \\
\hline 0.9 & 19.06 & 90.6 \\
\hline 1.2 & 23.56 & 135.6 \\
\hline 1.5 & 19.48 & 94.80 \\
\hline \multicolumn{3}{|c|}{ Soaked CBR value } \\
\hline 0 & 4.2 & - \\
\hline 0.3 & 5.92 & 41 \\
\hline 0.6 & 6.98 & 66.19 \\
\hline 0.9 & 7.68 & 82.85 \\
\hline 1.2 & 8.90 & 111.19 \\
\hline 1.5 & 7.86 & 87.14 \\
\hline
\end{tabular}

It was observed from the results as shown in Table.4 that there was an increase in both unsoaked and soaked CBR value of soil as the cotton fiber content is increased up to $1.2 \%$ after that there is a slight decrease in the CBR value at cotton fiber content of $1.5 \%$. From the Table. 4 it is clear that the maximum unsoaked CBR value is $23.56 \%$ at cotton fiber content of $1.2 \%$, which is 2.35 times that of unreinforced soil. It indicates that there was an increase of $135.6 \%$ in CBR value at $1.2 \%$ fiber content. It was also observed from the Table.4 that the maximum soaked CBR value is $8.90 \%$ at cotton fiber content of $1.2 \%$, which is 2.11 times that of unreinforced soil. It indicates that there was an increase of $111.19 \%$ in CBR value at $1.2 \%$ fiber content. However beyond $1.2 \%$ fiber content the value of CBR decreases and in case of soaked sample it is $7.86 \%$ at cotton fiber content of $1.5 \%$.

The CBR value increases due introduction of randomly distributed cotton fiber because the introduced fiber is incorporated into soil mass and is responsible for improvement in its load deformation behavior by interacting with soil particles mechanically through surface friction and interlocking. The bond or interlock is responsible for transfer of stress from soil to discrete inclusion by mobilizing the tensile strength of fiber inducted. The fiber reinforcement acts as a frictional and tension resistant element. Further addition of fiber makes the soil a composite material resulting in greater strength and stiffness as compared to unreinforced soil. This may be the reason also that CBR value of reinforced soil was found greater than that of unreinforced soil. The optimum cotton fiber content corresponding to maximum value of $\mathrm{CBR}$ was found to be $1.2 \%$ by dry weight of soil.

\section{Conclusions}

Based on the experimental investigations and study the following conclusions can be drawn-
1) There was an increase in CBR value of soil with the introduction of cotton fiber for both unsoaked and soaked conditions up to cotton fiber content of $1.2 \%$ after that there is a slight decrease in the CBR value at cotton fiber content of $1.5 \%$.

2) The maximum unsoaked CBR value is $23.56 \%$ at cotton fiber content of $1.2 \%$, which is 2.35 times that of unreinforced soil. It indicates that there was an increase of $135.6 \%$ in CBR value at $1.2 \%$ fiber content.

3) The maximum soaked CBR value is $8.90 \%$ at cotton fiber content of $1.2 \%$, which is 2.11 times that of unreinforced soil. It indicates that there was an increase of $111.19 \%$ in CBR value at $1.2 \%$ fiber content. However beyond $1.2 \%$ fiber content the value of CBR decreases and in case of soaked sample it is $7.86 \%$ at cotton fiber content of $1.5 \%$.

4) The optimum cotton fiber content corresponding to maximum value of CBR was found to be $1.2 \%$ by dry weight of soil.

\section{References}

[1] Aggarwal, P. and Sharma, B. (2010), Application of Jute Fibre in the Improvement of Subgrade Characteristics (SP), ACE 2010, Paper ID-41

[2] Fatani, N.M., Bauer, G.H., and Al-Joulani, N.(1999) Reinforcing soil with aligned and randomly oriented metallic, Journal of ASTM Geotech Testing (1), pp 7887.

[3] Gray, D.H., and Ohashi, H. (1983), Mechanics of fibre reinforcing in sand, Journal of Geotechnical Engineering ,ASCE 112(8):335-353.

[4] Gray, D.H., and Al-Refeai, T.(1986), Behaviour of fabric- versus fibre-reinforcd sand, Journal of Geotechnical Engineering, ASCE, 112(8): 804-820.

[5] IS: 2720, Part XVI, 1987, Laboratory determination of CBR, Bureau of Indian Standards; New Delhi.

[6] IS: 2720, Part VII, 1980, Determination of Moisure content -Dry density Relation using Light Compaction, Bureau of Indian Standards; New Delhi.

[7] Lawton E.C., Khire, M.V. and Fox, N.S. (1993). Reinforcement of soils by multioriented geosynthetic inclusion. Journal of Geotechnical Engineering ASCE, 119(2),257-275.

[8] Maher, M.H. and Gray, D.H. (1990). Static response of sands reinforced with randomly distributed fibres. Joumal of Geotechnical Engineering, ASCE. 716 (11), 1661-1677

[9] Singh, H.P. (2011), Strength Characteristics of Soil Reinforced With Geosynthetic, International Journal of Earth Sciences and Engineering ,Iol 04,No 06 SPL, October 2011,pp 969-971,2011.

[10] Singh, H.P. (2012), Improvement in CBR Value of Fly ash Reinforced with Coir fiber, 3rd International Conference on Natural Polymer (ICNP 2012), held at Mahatma Gandhi University Kottayam, Kerala, India. 26-27 October Paper No-118.

[11] Sivakumar Babu, G.L., and Vasudevan, A.K. (2008), Strength and Stiffness Response of Coir fiber Reinforced Tropical Soil, Journal of Materials in Civil Engineering, ASCE/, September, 571-578

[12] Singh, H.P., and Bagra, M. (2013), Improvement in CBR value of soil reinforced with Jute Fiber, 


\section{International Journal of Science and Research (IJSR) \\ ISSN (Online): 2319-7064}

Index Copernicus Value (2013): 6.14 | Impact Factor (2014): 5.611

International Journal of Innovative Research in Science, Engineering and Technology, 2 (8), 3447-3452

\section{Author Profile}

Brajesh Mishra received the B.E. and M. Tech. degrees in Civil Engineering from Madan Mohan Malviya Engineering College, Gorakhpur, India (NowMMMUT) in 1988 and KNIT, Sultanpur, India in 2014

respectively. At present working with U.P. Cane Development Department, Lucknow, responsible for construction of road projects. 